\title{
IMPLEMENTASI PARADIGMA POSTMODERNISME DALAM PEMBAHARUAN HUKUM DI INDONESIA SERTA KRITIK TERHADAPNYA
}

\author{
Romi Saputra \\ Mahasiswa S3 Program Doktor Ilmu Hukum UMS \\ romisaputra87@gmail.com
}

\begin{abstract}
This paper aims to reveal the paradigm of postmodernism through critical legal studies which have definitely and consciously been practiced by many countries in the world, including Indonesia. By using and driving the term, the new paradigm of postmodernism greatly influences the Indonesian nation's thinking in law. Postmodernism is a school, though, and attitude related to theoretical criticism that emphasizes relativity, anti-universality, nihilism, criticism of rationalism, criticism of universalism, criticism of fundamentalism or science. The research method used in this type of research is qualitative research using a legal concept approach with data collection methods derived from the literature (library research). The results of this study found that the Postmodernism paradigm emerged as a critique of Modernism. Modernism as expressed by Anthony Giddens, that modernism causes a big disaster for mankind, namely the use of violence in resolving disputes, the strong oppress the weak, rampant social inequality, and the destruction of life which is increasingly worrying. The critical note of the Postmodernism paradigm when it is implemented in the renewal of Islamic law in Indonesia in the form of the theory of Critical Legal Studies is full of secularism, so that the reforms that are to be initiated and echoed if implemented in Islamic law can eliminate the sacredness of Islamic law itself so that it is no longer visible. differences in which principles are tsawabit and which are mutaghayirat, this will lead to doubt and loss of the values of Islamic law as outlined in the Qur'an, hadith, and the opinions of scholars.
\end{abstract}

Keywords: Postmodernism, Legal Reform, Criticism

\begin{abstract}
Tulisan ini bertujuan untuk menyingkap paradigma postmodernisme melalui critial legal studies yang secara pasti dan sadar sudah banyak diamalkan oleh negara-negara di dunia tidak terkecuali negara indonesia. Dengan memakai dan mengendarai istilah paradigma baru postmodernisme sangat mempengaruhi alam berfikir bangsa indonesia dalam berhukum. Posmodernisme adalah suatu aliran, pemikiran, dan sikap yang berkaitan dengan kritik teoritikal yang menekankan pada relativitas, anti universalitas, nihilist, kritik terhadap rasionalisme, kritik terhadap universalisme, kritik terhadap fundamentalisme atau sains. Adapun metode penelitian yang digunakan adalah Jenis Penelitian adalah penelitian kualitatif dengan memakai pendekatan konsep hukum dengan metode pengumpulan datanya berasal dari literatur (library research). hasil dari penelitian ini didapatkan bahwa paradigam Postmodernisme kemunculanya dilatarbelakangi sebagai kritik dari Modernisme. Modenisme sebagaimana diungkapkan oleh Anthony Giddens, bahwa modernisme menimbulkan petaka besar bagi umat manusia, yaitu penggunaan kekerasan dalam menyelesaikan sengketa, yang kuat menindas yang lemah, maraknya ketimpangan sosial, dan rusaknya kehidupan yang kian mengkhawatirkan. Adapun catatan kritis dari dari paradigma Postmodernisme ini ketika diimplementasikan dalam pembaharuan hukum islam di indonesia dalam bentuk teori Criticl Legal Studies sarat dengan Sekularisme, sehingga pembaharuan yang hendak digagas dan digaungkan jika terimplementasi dalam hukum islam dapat menghilangkan kesakralan dari hukum islam itu sendiri sehingga tidak tampak lagi perbedaan dalam prinsip mana yang tsawabit dan mana yang mutaghayirat, hal ini akan berujung kepada keraguan dan kehilangan dari nilai-nilai hukum islam sebagaimana yang telah digariskan didalam al quran, hadits dan pendapat para ulama.
\end{abstract}

Kata Kunci: Postmodernisme, Reformasi Hukum, Kritik 


\section{PENDAHULUAN}

Pada awal abad ke-16 sampai puncaknya di abad ke-18 muncullah abad Pencerahan (Aufklarung). Pada zaman itu, manusia tidak lagi memandang alam sebagai sebuah isteri besar, melainkan alam yang dapat diukur dan dipahami sedetail mungkin dengan sains. Berkembangnya paham positivisme juga mulai menjangkiti masyarakat di Eropa kala itu, masyarakat tidak lagi percaya pada mitos-mitos, namun pada fakta empiris. Dengan hadirnya paham tersebut, fenomena alam mulai mendapatkan penjelasan ilmiahnya, dan jejak-jejak metafisik tentang alam mulai hilang tertiup angin. Di abad ke-19 dan 20 dunia mengalami zaman modern yang penuh dengan hiruk-pikuk mulai dari pertarungan ideologi, Perang Dunia I dan II, kolonialisme, serta kekacauan yang hadir karena keponggahan manusia dalam memandang dunia hanya dengan melalui rasio. Dunia seolah dipilah-pilah oleh sains dan tidak ada tempat untuk mengutarakan pendapat atau emosi dari pihak subjek. Setelah itu lahirlah aliran postmodernisme yang didasari oleh ketidakpercayaan terhadap aliran modernisme yang dianggap telah gagal mewujudkan cita-cita yang mereka agungagungkan yaitu ingin menyejahterakan seluruh umat manusia, tetapi malah sebaliknya, aliran modernisme dianggap telah gagal dan merusak tatanan kehidupan masyarakat. Modernisme justru menciptakan masyarakat yang terlalu individualistik, yang kaya semakin kaya, yang miskin semakin miskin, dan yang pintar membodohi orang yang bodoh, serta negara yang kuat menjajah negara yang lemah.

\section{METODE PENELITIAN}

Jenis penelitian ini adalah penelitian kualitatif bersifat Deskriptif analitis yakni penelitian hukum dimana pengetahuan atau teori tentang obyek sudah ada dan ingin memberikan gambaran tentang obyek penelitian. Sementara pendekatan yang digunakan adalah pendekatan perundangundangan dan pendekatan konseptual.

Pendekatan perundang-undangan (statute approach) merupakan penelitian yang mengutamakan bahan hukum yang berupa peraturan perundang-undangan sebagai bahan acuan dasar dalam melakukan penelitian Pendekatan konseptual (conceptual approach) merupakan jenis pendekatan dalam penelitian hukum yang memberikan sudut pandang analisa penyelesaian permasalahan dalam penelitian hukum dilihat dari aspek konsep-konsep hukum yang melatarbelakanginya, atau bahkan dapat dilihat dari nilai-nilai yang terkandung dalam penormaan sebuah peraturan kaitannya dengan konsep-konsep yang digunakan. Sementara teknik pengumpulan datanya berasal dari literatur atau disebut juga penelitian ini dengan library research.

\section{PEMBAHASAN}

\section{A. Defenisi Postmodernisme}

Secara harfiah Postmodern adalah setelah moderen yang berarti zaman baru untuk menunjuk kepada batas antara era kekuasaan agama kristen dan era paganisme romawi (Smart, 2016). Pawitro (2010) menjelaskan posmodernisme adalah suatu aliran, pemikiran, dan sikap yang berkaitan dengan kritik teoritikal yang menekankan pada relativitas, anti universalitas, nihilist, kritik terhadap rasionalisme, kritik terhadap universalisme, kritik terhadap fundamentalis atau sains. Postmodern dapat diartikan sebagai paradigma yang menolak paham modernisme karena dianggap gagal dan bertanggung jawab terhadap kehancuran martabat manusia dengan memberikan kritikan-kritikan terhadapnya dan menggeser ide-ide 
moderen menjadi ide yang baru (Setiawan \& Sudrajat, 2018).

MODERNISEM

\begin{tabular}{ll}
\hline Sentralisasi & Desentralisasi \\
\hline Pertarungan kelas & Pertarungan etnis \\
\hline Kontruksi & Dekonstruksi \\
\hline Hermeneutic & Nihilisme \\
\hline Budaya tinggi & Budaya rendah \\
\hline Hierarki & Anarki \\
\hline Industri & Pasca Industri \\
\hline Teori & Paradigma \\
\hline Kekuatan negara & Kekuatan bersama \\
\hline Agama & Sekte-Sekte \\
\hline Legitimasi & Delegitimasi \\
\hline Konsensus & Dekonsensus \\
\hline Budaya tradisional & Liberalisme \\
\hline Kontuinitas & Diskontuinitas \\
\hline Pertarungan kelas & Pertarungan etnis \\
\hline
\end{tabular}

Capra dalam bukunya Tao of Physics mengartikan paradigma sebagaisebuah asumsi dasar yang membutuhkan bukti pendukung untuk asumsi-asumsi yang ditegakanya, dalam menggambarkan dan mewarnai interperetasinya terhadap realita sejarah sains. Khun dalam karyanya The Structure of Scientific Revolution mengemukakan pengertian paradigma adalah gabungan hasil kajian yang terdiri dari seperangkat konsep, nilai, teknik dan lain-lain yang digunakan secara bersama dalam suatu komunitas untuk menentukan keabsahan sutu masalah beserta solusinya.

Maka jika Postmodern dimaknai sebagai sebuah paradigma artinya adalah Postmodern sebagai suatu konsep yang membentuk kerangka berfikir yang bertujuan untuk memahami, menafsirkan, mengkaji, memberi solusi dan menjelaskan kenyataan yang berkaitan dengan fenomena sosialbudaya dalam kehidupan masyarakat (Ilham, 2018). Sebagai sebuah paradigma dalam ilmu sosial-budaya, menurut Ahimsa setidaknya ada 9 unsur yang mendukungnya sebagai sebuah paradigma, yaitu: asumsiasumsi dasar, nilai-nilai (values), masalah yang ingin diteliti, model, konsep-konsep, metode penelitia, metode analisis, hasil analisis, dan etnografi atau representasi (Ilham, 2018)
Ilham (2018) menjelaskan setidaknya ada 2 unsur kandungan dalam Paradigma Postmodernisme, yaitu:

1. Asumsi-Asumsi dan Nilai

Nilai-nilai kebenaran bersifat relatif. Artinya dalam paradigma ini setiap individu berhak menginterpretasi mengenai segala sesuatu atau fenomena sosial yang dilihat dan dirasa sesuai dengan apa yang ada dalam pikiranya, sehingga kebenaran disini sangat relatif karena setiap individu memiliki penafsiran yang berbeda-beda terhadap sebuah fenomena.

Tidak percaya dengan narasi-narasi besar yang telah lalu, semisal pemikiran Hegel. Dalam filsafat dialektika Hegel, ia terpengaruh oleh pemikiran Immanuel Kant, Hegel mengatakan pengetahuan adalah on going process, dimana apa yang diketahui dan aku yang mengetahui terus berkembang, tahap yang sudah tercapai disangkal atau dinegasi oleh tahap baru. Tahap yang lama itu bukan berarti tidak berlaku lagi akan tetapi dilihat sebagai sesuatu yang terbatas (Husaini, 2020)

2. Ciri pemikiran Postmodernisme

Rosenau mengatakan bahwa Postmodernisme hadir sebagai kritik terhadap aliran modernisme yang gagal memenuhi janji kehidupan sosial yang lebih baik. Cenderung menolak metanarasi, totalitas, dan pandangan besar dunia. Postmodernisme lebih menerima penjelasan yang sangat terbatas (lokal naratif) untuk mengisi kehidupan. Cenderung melihat fenomena emosional pra-modern seperti emosi, perasaaan, intuisi, refleksi, spekulasi, tradisi, kosmologi, magis, mitos, sentimen keagamaan, dan pengalaman mistik Menolak gaya diskursus akademis modern yang teliti dan bernalar, karena tujuan dari penganut paradigma Postmodern adalah mengagetkan 
pembaca dengan logika-logika argumentatif.

Dari penjelasan diatas setidak ada 2 karakter dari Postmodernisme, yaitu, pertama. Dekonstruktif artinya dasar keilmuan yang telah mapan pada masa modernisme (psikologi, sosiologi, sejarah, antropologi, dan ilmu-ilmu alam) dipertanyakan kembali oleh Postmodern. Jadi hal-hal yang sudah baku, standar dan tidak boleh diganggu gugat itulah yang ditentang oleh Postmodernisme. kedua, berwatak Relativisme artinya adalah nilai-nilai budaya bersifat relatif, bahwa budaya, bahasa, agama, sangat ditentukan oleh tata nilai dan adat istiadat masingmasing sebagaimana banyak tergambar dalam teori-teori disiplin antropologi. Disinilah letak relatifnya dan tidak ada ilmu pengetahuan kebenaranya absolut karena harus mempertimbangkan situasi dan kondisi yang ada (Ilham, 2018).

\section{B. Latar Belakang Munculnya Gagasan Posmodernisme}

Postmodernisme adalah istilah yang pertama kali muncul dikalangan seniman dan kritikus di New York pada tahun 1960an, selanjutnya diambil oleh oleh teoretikus eropa tahun 1970-an (Husaini, 2020). Diantaranya Jean Francois Lyotard dalam karyanya The Postmodern Condition: A Reoport on Knowlodge menyerang mitos yang meligitimasi zaman moderen, pembebasan progresif humanitas melalui ilmu, dan gagasan bahwa filsafat dapat memulihkan kesatuan untuk proses memahami dan mengembangakan pengetahuan secara universal sahih untuk seluruh umat manusia (Ryadi, 2004).

Postmodernisme merupakan suatu paradigma yang lahir sebagai kritik dari Modernisme. Modernisme sebagaimana diungkapkan oleh Max Horkheimer, Ardono, dan Herbert Marcuse yaitu ia memiliki sisi kelam yang membuat manusia kehilangan diorientasi sehingga melahirkan penindasan dan dominasi mesikipun tidak menutup juga melahirkan kemajuan. Hal yang senada disampaikan pula oleh Anthony Giddens, bahwa modernisme menimbulkan petaka besar bagi umat manusia, yaitu penggunaan kekerasan dalam menyelesaikan sengketa, yang kuat menindas yang lemah, maraknya ketimpangan sosial, dan rusaknya kehidupan yang kian mengkhawatirkan (Setiawan \& Sudrajat, 2018)

Prinsip pengetahuan era postmodern tidak lagi diligitimasi pada kesatuan ontologis melainkan pada paralogy. Kemajuan dan rasionalisasi yang digaungkan oleh modernitas lebih mengembangkan prinsip homology dan mengenyampingkan paralogy. Pola berfikir seperti inilah yang dikritik oleh postmodern karena bangunan epistimologi melahirkan masyarakat moderen yang chaos sebagai implikasi penerapan penerapan prinsip epistimologi yang memberangus munculnya alternatif kebenaran-kebenaran (A. R. Hidayat, 2006). Kritik Postmodernisme terhadap bangunan modernisme, Nietzsche menyebutnya dengan fase yang dipandang sebagai gejala Nihilisme kebudayaan barat modern. Gagasan dasar seperti filsafat, rasionalitas, dan epistimologi dicurigai dan dipertanyakan kembali secara radikal

Hidayat (2019) menjelaskan dalam perkembanganya postmodernism dibagi menjadi 2 bentuk:

1. Postmodernisme sebagai paradigma pemikiran yang meliputi 3 aspek yaitu ontologi, epistemologi, dan aksiologi. Tokoh-tokohnya diantaranya Lyotard, Derrida, dan Foucault.

2. Postmodernisme sebagai metode analisis kebudayaan masyarakat kontemporer. Tokoh-tokohnya adalah Rortry dan Baudrillard. 


\section{Teori-teori Postmodernisme dan penerapanya dalam Ilmu Hukum}

1. Teori-Teori Postmodernisme

Setiawan \& Sudrajat (2018) menjelaskan ada beberapa teori sosial Postmodernisme, diantaranya Teori Postmodern Moderat, teori ini menyatakan bahwa ada keterputusan antara modernisme dengan postmodernisme. Meskipun ada perbedaan penting antara postmodernisme dengan modernisme, terdapat juga pertalian antara keduanya. Menurut Jamesson, masyarakat postmodern terdiri atas: ditandai dengan kedangkalan dan kekurangdalaman, keberpura-puraan atau kelesuan ekonomi, hilangnya kesejarahan.

Sejenis tekhnologi baru yang berkaitan erat dengan masyarakat postmodern. Contoh tekhologi televisi dan tekhnologi elektronik. Kedua, teori postmodern ekstrem, teori ini menyatakan bahwa masyarakat moderen telah digantikan oleh masyarakat postmodern. Tokohnya adalah Jean Baudrillard, ia mengatakan keadaan sosial masyarakat saat ini dipengaruhi oleh berbagai produksi yang memperlihatkan keadaan sesungguhnya masyarakat itu. Hal yang mempengaruhi dan mendominasinya adalah media dan siberanertika dan industri. Disaat masyarakat didominasi oleh kode produksi dan dikontrol olehnya maka hal ini bertujuan ntuk eksploitasi dan laba menuju kerah tanda dan sistem. Saat itu dunia digambarkan sebagai Hipperealitas yaitu sulit untuk melihat yang riil. Secara lebih khusus paradigma postmodern tergambar dari beberapa teori, diantaranya:

2. Teori Jean Francois Lyotard: Narasi Besar dan Masyarakat Komputerisasi

Telah terjadi perubahan dalam realitas masyarakat, yang ditandai dengan penolakan terhadap apa yang ia sebut dengan narasi besar (Grand Narratives). Ciri utama dari kebudayaan postmodern adalah lahirnya masyarakat komuterisasi, runtuhnya narasi-narasi besar modernisme, lahirnya prinsip delegitimasi, disensus, serta paralogi (heterologi).

3. Jaques Derida: Teori Dekonstruksi

Teori Dekonstruksi merupakan teori yang secara radikal mentransformasikan pemahaman tentang tulisan, pembacaan dan teks. Menurutnya gagasan kunci dari dekonstruksi adalah: differance, tilas, suplemen, teks, iterabilitas, ketiadaan putusan, dan diseminasi. Contoh penerapan teori ini adalah dipakai dalam strategi pembacaan teks sastra (Ungkang, 2013)

4. Teori Relativisme

Secara etimologis, relativisme yang dalam bahasa Inggrisnya relativism, relative berasal dari bahasa latin relativus (berhubungan dengan). Dalam penerapan epistemologisnya, ajaran ini menyatakan bahwa semua kebenaran adalah relatif. Penggagas utama paham ini adalah Protagoras, Pyrrho (Lorens, 2005). Makna relativisme seperti yang tertera dalam Ensiklopedi Britannica bahwa dalam paham relativisme apa yang dikatakan benar atau salah; baik atau buruk tidak bersifat mutlak, tapi senantiasa berubah-ubah dan bersifat relatif tergantung pada individu, lingkungan maupun kondisi sosial.

Di zaman Barat postmodern doktrin ini dicetuskan oleh F. Nietzsche dengan doktrin yang disebut nihilisme yang intinya adalah relativisme (Zarkasyi, 2009). Nihilisme hakikatnya tidak mempercayai segala sesuatu termasuk tuhan sesungguhnya tidak ada. Tujuan nihilisme adalah untuk memutuskan dan mengakhiri keputusan terhada kebenaran pemikiran metafisis tradisional (Ridho, 2017) Ungkapannya yang terkenal yaitu 
"Der Gott ist tot" (tuhan sudah mati) ia mengungkapkan :"Tuhan sudah mati, tuhan tetap mati dan kita telah membunuhnya ...." Tidakkah seharusnya kita sendiri menjadi tuhan-tuhan semata supaya layak akan hal itu. Dengan makna ini Nietzsche mengatakan bahwa gagasan tentang tuhan tidak lagi mampu untuk berperan sebagai sumber dari semua aturan moral atau teleologi

5. Pluralisme Agama

Karl Rahner seorang ahli teologi terkemuka mengatakan, bahwa orangorang dari agama lain akan mendapatkan keselamatan dengan rahmat tuhan, walaupun kekal dalam agama mereka. C.S. Lewis mengatakan: saya berfikir bahwa setiap doa yang dilakukan dengan tulus ikhlas walaupun terhadap tuhan palsu ... akan diterima oleh tuhan yang benar dan bahwa Jesus akan menyelamatkan ramai orang yang tidak mengenalinya (Harris, 2018).

Jhon Hick mengatakan bahwa pada dasarnya semua gambaran tentang tuhan atau yang hakiki sebenarnya tidak dapat dijangkau oleh pengetahuan manusia dan yang tergambar hanyalah yang dapat dialami oleh keterbatasan manusia, maka kebenaran yang dicapainya hanyalah kebenaran yang palsu. Manusia tidak akan pernah sampai kepada kebenaran objektif, kebenaran objektif hanyalah bayangan manusia. Bagi Hick tuhan agama islam, agama hindu dan buda adalah sama sahaja. Seseorang yang percaya bahwa allah ialah pencipta alam semesta sama dengan yang percaya bahwa alam ini adalah kekal dan ianya sendiri adalah tuhan pada hakikatnya sama sahaja (Harris, 2018)

\section{Implementasi Postmodernisme dalam} Pembaharuan Hukum di Indonesia Serta Kritik Terhadapnya
Penerapan Postmonernisme dalam ilmu hukum diataranya adalah dalam bentuk lahirnya aliran Critical Legal Studies. Critical Legal Studies adalah salah satu bagian dari critical legal theory. Setidaknya critical legal theory memayung 4 (empat) cabang teori yaitu: feminist legal theory (FLT), critical race theory (CRT),postmodern jurisprudence (PJ), dan critical legal studies (CLS) (Tanya et al., 2013)

Critical Legal Studies merupakan sebuah gerakan yang muncul pada tahun tujuh puluhan di Amerika Serikat. Gerakan ini merupakan kelanjutan dari aliran hukum realisme Amerika yang menginginkan suatu pendekatan yang berbeda dalam memahami hukum, tidak hanya seperti pemahaman selama ini yang bersifat Socratis. Beberapa nama yang menjadi penggerak Critical Legal Studies adalah Roberto Unger, Duncan Kennedy, Karl Klare, Peter Gabel, Mark Tushnet, Kelman, David trubeck, Horowitz, dan yang lainnya (Purwanto, n.d.)

Para teoritisi postmodern percaya, pada prinsipnya hukum tidak mempunyai dasar yang objektif dan tidak ada yang namanya kebenaran sebagai tempat berpijak dari hukum. Dengan kata lain, hukum tidak mempunyai dasar berpijak, yang ada hanya kekuasaan. Akhir-akhir ini, mereka yang disebut juga dengan golongan antifoundationalistis, telah mendominasi pikiran-pikiran tentang teori hukum dan merupakan pembela gerakan Critical Legal Studies (Purwanto, n.d.)

Fokus sentral pendekatan critical legal studies adalah untuk mendalami dan menganalisis keberadaan doktrin-doktrin hukum, pendidikan hukum dan praktek institusi hukum yang menopang dan mendukung sistem hubungan-hubungan yang oppressive (bersifat menindas) dan tidak egaliter. Teori kritis bekerja untuk mengembangkan alternatif lain yang radikal, dan untuk menjajagi peran hukum dalam 
menciptakan hubungan politik, ekonomi dan sosial yang dapat mendorong terciptanya emansipasi kemanusiaan. Dalam perkembangan lebih lanjut, pendekatan critical legal studies telah melahirkan generasi kedua yang lebih Menitik beratkan pemikiran dan perjuangannya dengan menggunakan hukum untuk merekontruksi kembali realitas sosial yang baru (Purwanto, n.d.)

Sebagaimana yang telah dijelaskan diawal tulisan ini bahwa dekonstruki merupakan salah satu metode analisis hukum dari critical legal studies (CLS). Wacana dekonstruksi pertama kali digulirkan oleh Martin Heidegger dan Jacques Derrida yang kemudian dipatenkan oleh para posmodernis. Dalam melakukan dekonstruksi, Derrida mengajukan dua pendekatan. Pendekatan pertama, ia menggunakan ilmu tulis ( $a$ science of writing) yang kemudian dinamainya sebagai grammatology. Dalam pendekatan pertama ini yang penting adalah membangun sebuah keberanian untuk melakukan pembongkaran terhadap teks (to encourage the deconstruction of texs) dengan disertai atau mengikuti logika identitas (a logic of identity). Pendekatan kedua, ia gunakan prinsip yang disebut difference, yaitu kerja membedakan dalam konteks ruang (to differ in space) dan menunda dalam konteks waktu dan kehadiran (to defer means to put off in time or to postpone presence). Implementasi paradigma posmodernisme dengan mengendarai aliran critical legal studies tentu menjadi ancaman yang serius terutama jika dipakaikan kepada hukum yang berkembang di indonesia. Sebagaimana diketahui bahwa negara indonesia menganut pluralitas hukum yaitu (hukum barat, hukum islam, dan hukum adat) yang kemudian menjadi hukum positif yang berlaku untuk bangsa indonesia. Hukum Islam Misalnya pembagian hasil warisan antara laki-laki dan perempuan yang sudah dibakukan oleh Al quran, persoalan tentang kebolehan laki-laki berpoligami yang dengan jelas digariskan oleh Al-Quran, sementara perempuan tidak boleh, perempuan memiliki masa idah jika diceraikan oleh suminya, sementara laki-laki tidak memiliki masa idah jika terjadi kasus perceraian. Hal-hal seperti ini tentu dinilai sebagai bentuk ketidakadilan dan diskriminasi terhadap hak asasi manusia yang didasarkan kepada gender, jika dilihat dari sudut pandang critical legal studies tentu kita masih ingat dengan gagasan pembaharuan hukum islam yang digagas oleh Tim Pengarusutamaan Gender (PUG) yang menghendaki pembaharuan terhadap Kompilasi Hukum Islam dengan wacana Counter Legal Draft-KHI.

Menurut PUG, mengkritik KHI (kompilasi hukum islam) dengan pandangan bahwa KHI tidak lagi memadai dan tidak cukup mampu menyelesaikan persoalan yang sangat komplek. CLD-KHI dengan paradigma gender, pluralisme, HAM, dan demokrasi mengatakan KHI lebih didominasi oleh mazhab syafii sehingga tidak akrab dengan hukum nasional dan internasional yang mencita-citakan tegaknya masyarakat yang egaliter, demokrasi, dan pluralis. $^{28}$ Tim PUG tidak hanya menginginkan perubahan subtansi (pasalpasal) dalam KHI, tapi juga menginginkan perubahan pada paradigma. Berikut perubahan-perubahan yang diinginkan

\section{Catatan kritis terhadap Paradigma Postmoedernisme}

Paradigma postmodernisme melalui aliran/teori Critical Legal Studies membuat kabur hal-hal yang sangat prinsip dalam bangunan hukum di indonesia terutama hukum islam:

Pertama, tidak berbeda lagi mana yang tsawabit dan mana yang mutaghayirat di dalam agama, atau sangat sulit dipahami mana hal yang bersifat ushul dan mana yang bersifat furu' sehingga berujung dengan keraguan dan kerancuan dalam 
pemahamanya, karena corak dari postmodernisme yang berani mendobrak halhal yang sudah baku dan bersifat permanen atas dasar kecurigaan dan mengusung pembaharuan. Tsawabit dan mutaghayirat adalah dua istilah yang dimaksudkan untuk membedakan antara berbagai persoalan yang telah disepakati dan ditunjukan oleh nashnash qat'i yang tidak boleh ada perselisihan tentangnya, keluar darinya maka dianggap keluar dari keimanan.

Tsawabit adalah hal-hal Qat'i yang telah disepakati ulama, yang telah dikukuhkan hujahnya oleh allah swt dalam al quran dan lewat lisan Nabi-Nya dengan sejelas-jelasnya hingga tidak ada peluang untuk pengembangan atau ijtihad tentangnya dan tidak boleh berselisih pendapat tentangnya. Ruang lingkup tsawabit adalah ketentuan-ketentuan umum syariat, mayoritas masalah akidah, pokok-pokok masalah fardhu, pokok-pokok yang diharamkan, pokok-pokok keutamaan, dan akhlak. Sedangkan lapanganya yang paling menonjol adalah dalam aqidah, ibadah, akhlak, dan prinsip-prinsip muamalah

Contohnya dalam ibadah (hukum) adalah sebagai berikut Mengenai warisan Dan bagimu (suami-suami) seperdua dari harta yang ditinggalkan oleh isteri-isterimu, jika mereka tidak mempunyai anak. Jika isteri-isterimu itu mempunyai anak, maka kamu mendapat seperempat dari harta yang ditinggalkannya sesudah dipenuhi wasiat yang mereka buat atau (dan) seduah dibayar hutangnya. Para isteri memperoleh seperempat harta yang kamu tinggalkan jika kamu tidak mempunyai anak. Jika kamu mempunyai anak, maka para isteri memperoleh seperdelapan dari harta yang kamu tinggalkan sesudah dipenuhi wasiat yang kamu buat atau (dan) sesudah dibayar hutang-hutangmu. Jika seseorang mati, baik laki-laki maupun perempuan yang tidak meninggalkan ayah dan tidak meninggalkan anak, tetapi mempunyai seorang saudara laki-laki (seibu saja) atau seorang saudara perempuan (seibu saja), maka bagi masingmasing dari kedua jenis saudara itu seperenam harta.

Jika saudara-saudara seibu itu lebih dari seorang, maka mereka bersekutu dalam yang sepertiga itu, sesudah dipenuhi wasiat yang dibuat olehnya atau sesudah dibayar hutangnya dengan tidak memberi mudharat (kepada ahli waris). (Allah menetapkan yang demikian itu sebagai) syari'at yang benarbenar dari Allah, dan Allah Maha Mengetahui lagi Maha Penyantun. (Q.s Anisa: 12) Wajibnya masa idah bagi perempuan "Wanita-wanita yang ditalak handaklah menahan diri (menunggu) tiga quru'." (Al-Baqoroh : 228)

"Dan perempuan-perempuan yang tidak haid lagi (monopause) di antara perempuanperempuanmu jika kamu ragu-ragu (tentang masa iddahnya), Maka masa iddah mereka adalah tiga bulan; dan begitu (pula) perempuan-perempuan yang tidak haid. dan perempuan-perempuan yang hamil, waktu iddah mereka itu ialah sampai mereka melahirkan kandungannya." (at-Thalaq : 4)

\section{Kepemimpinan Laki-Laki Atas Perempuan}

"Kaum laki-laki itu adalah pemimpin bagi kaum wanita, oleh karena Allah telah melebihkan sebagian mereka (laki-laki) atas sebagian yang lain (wanita), dan karena mereka (laki-laki) telah menafkahkan sebagian dari harta mereka. Sebab itu maka wanita yang shalih ialah yang taat kepada Allah lagi memelihara diri ketika suaminya tidak ada, oleh karena Allah telah memelihara (mereka). (An-Nisaa': 34)

Hukuman zina ghairu muhsan adalah didera 100 kali cambuk "(Ini adalah) satu surah yang Kami turunkan dan Kami wajibkan (menjalankan hukum-hukum yang ada di dalam)nya, dan Kami turunkan di dalamnya ayat-ayat yang jelas, agar kamu selalu mengingatinya. Perempuan yang 
berzina dan laki-laki yang berzina, maka deralah tiap-tiap seorang dari keduanya seratus kali cambukan, dan janganlah belas kasihan kepada keduanya mencegah kamu untuk (menjalankan) agama Allah, jika kamu beriman kepada Allah dan hari akhirat, dan hendaklah (pelaksanaan) hukuman mereka disaksikan oleh sekumpulan orang-orang yang beriman.” (QS. An-Nur: 1-2).

Kedua, tidak lagi berorientasi kepada Maqashid al Syariyyah, Maqashid al syariyah adalah tujuan diturunkanya syariat ini yaitu, untuk menjaga agama, menjaga jiwa, menjaga harta, menjaga keturunan,dan menjaga akal. Semua hukum islam yang ditetapkan maka berorientasi dan bermuara kepada 5 bentuk maqashid syariyah ini. Tampak sekali sekularistik dan bahaya dari postmodernise itu karena memang hal yang sangat ditekankan itu adalah mendobrak keyakinan agama dengan pola dokonstruksi, sehingga dengan pola yang demikian terpisahkan antara subtansi pengaturanya dengan maksud dan tujuan dari subtansi tersebut. Atau dengan bahasa lainya terpisahnya antara hukum dengan spirit agama.

Salah satu contohnya adalah digagasnya metode hermeneutik untuk menafsirkan al quran sebagai salah satu sumber hukum didalam islam oleh tokohtokoh liberal seperti Dr. Muhammad Arkoun dengan gagasanya pembaharuan nalar islam, Dr. Nasr Hamid Abu Zaid dengan menerapkan metode dialektika supaya makna-makna terbebas dari otoritas makna tekstual sehinga tunduk kepada pemahaman historis dengan proses dialektis antara makna teks dengan signifikansinya dan pemikiran hermeneutik Dr. Hasan Hanafi Prof. Wan Mohd Nor Wan Daud mengatakan sesungguhnya penafsiran al quran sama sekali tidak boleh disamakan dengan hermeneutika yunani dengan cara apapun atau hermeneutika bibel menurut umat kristiani (Salim \& Kurniawan, 2010).
Juga tidak sama dengan semua teori takwil kitab suci yang menyatu pada peradaban dan agama-agama lain. Pasalnya ilmu tafsir al quran dianggap sebagai seluruh ilmu dasar yang membangun seluruh ilmu dalam belantara peradaba islam.34 Bagaimana mungkin metode tafsir bibel disamakan dengan dipakaikan kepada metode menafsirkan al quran?, bagaimana mungkin bibel dan al quran bisa dipersamakan, dan bagaimana mungkin penafsiran hermeneutik ini akan mampu menjaga kemurniaan agama islam sementara muatanya adalah sekularisme, pluralisme dan liberalisme dengan metode dekonstruksi meragukan hal-hal yang sudah dibakukan dalam hukum islam.

\section{KESIMPULAN}

1. Postmodernisme lahir merupakan sebagai kritik dari arus modernisme yang dianggap banyak medatangkan kerugian dalam kehidupan manusia.

2. Karakter bangsa indonesia yang majemuk berdampak kepada bentuk bangunan hukumnya yang plural yaitu hukum barat, hukum adat, dan hukum islam berlaku pada waktu yang sama untuk menata kehidupan bangsa indonesia .

3. Penerapan Posmodernisme dalam ilmu hukum dapat memakai pendekatan salah satunya teori critical legal studies. Namun pendekatan Postmodernisme melalui Critical Legal Studies akan menimbulkan masalah besar jika dipakaikan untuk menganalisis hukum islam karena berujung kepada Sekularisme, Pluralisme, dan Liberalisme. Sehingga dapat menghilangkan kesakralan dalam hukum islam, teruma hilangnya nilai-nilai keimanan, nilai- nilai prinsip dan hilangnya maksud dan tujuan dari ditetapkanya hukum. Dan bahkan postmodernisme menimbulkan kerancuan dan keraguan dalam subtansi hukum 
islam melalui critical legal studies tersebut.

\section{REFERENSI}

Harris, K. M. A. (2018). Islam dan Liberalisme: Antara Maá1£ laá, $¥$ ah dan Mafsadah: Islam and Liberalism: Between Benefit and Harm. AfkarJurnal Akidah \& Pemikiran Islam, 20(2), 1-52.

Hidayat, A. R. (2006). Implikasi postmodernisme dalam pendidikan. TADRIS: Jurnal Pendidikan Islam, $1(1)$.

Hidayat, M. A. (2019). Menimbang TeoriTeori Sosial Postmodern: Sejarah, Pemikiran, Kritik Dan Masa Depan Postmodernisme. Journal of Urban Sociology, 2(1), 42-64.

Husaini, A. (2020). Filsafat Ilmu: Perspektif Barat \& Islam. Gema Insani.

Ilham, I. (2018). Paradigma Postmodernisme; Solusi Untuk Kehidupan Sosial? Jurnal Sosiologi USK (Media Pemikiran \& Aplikasi), 12(1), 1-23.

Lorens Bagus, Kamus Filsafat, (Jakarta: Gramedia Pustaka Utama 2005)Penelusuran Google. (n.d.). Retrieved June 28, 2021,

Pawitro, U. (2010). Fenomena PostModernisme dalam Arsitektur Abad ke-21. Jurnal Itenas Rekayasa, 14(1).

Purwanto, M. E. (n.d.). Cabang besar filsafat, yatu teori pengetahuan, teori hakikat, dan teori nilai.

Ridho Ramazani bin Cecep, M. (2017). MOHANDAS KARAMCHAND GANDHI'S VIEWS ON GOD.

Ryadi, A. (2004). Postmodernisme versus modernisme. Studia Philosophica et Theologica, 4(2), 90-100.

Salim, F., \& Kurniawan, H. (2010). Kritik terhadap studi al-Qur'an kaum liberal. Perspektif.

Setiawan, J., \& Sudrajat, A. (2018). Pemikiran postmodernisme dan pandangannya terhadap ilmu pengetahuan. Gadjah Mada University. Smart, B. (2016). Postmodernity. Routledge. Tanya, B. L., Simanjuntak, Y. N., \& Hage, M. Y. (2013). Teori Hukum.

Ungkang, M. (2013). Dekonstruksi Jaques Derrida sebagai strategi pembacaan teks sastra. Jurnal Pendidikan Humaniora, 1(1), 30-37.

Zarkasyi, H. F. (2009). Liberalisasi pemikiran Islam: Gerakan bersama missionaris, orientalis dan kolonialis. Tsaqafah, 5(1), 1-28. 